\title{
Pain reliefe in viral infections. What role does ozone play? [abstract]
}

\author{
Carmela Imperiale, Fabio Silvio Mario Morselli Araimo, Paolo Tordiglione \\ Department of Anesthesiology Critical Care and Pain Medicine- University "Sapienza of Rome"- Rome- Italy
}

\section{ABSTRACT}

\section{OPEN ACCESS}

\section{Citation}

Imperiale C, Morselli-Araimo FS Tordiglione P. Pain reliefe in viral infections. What role does ozone play? [abstract]. Proceedings of The World Conference on Ozone Therapy in Medicine, Dentistry and Veterinary. Ancona (Italy). September 22nd - 23rd - 24th , 2017. J Ozone Ther. 2019;3(4):28. doi: 10.7203/ jo3t.3.4.2019.15509

\section{Academic Editor \\ Jose Baeza-Noci, \\ School of Medicine, Valencia University,} SPAIN

\section{Editor}

World Federation of Ozone Therapy, Bolgna, ITALY

\section{Received}

June 17, 2019

\section{Accepted}

December 08, 2019

\section{Published}

December 30, 2019

\section{Intellectual Property}

Carmela Imperiale.

This is an open access article distributed under the terms of the Creative Commons Attribution License (CC BY 4.0), which permits unrestricted use, distribution, and reproduction in any medium, provided the original author and source are credited.

\section{Author Information}

c.imperiale@me.com
Purpose. This preliminary study aim to investigate the role of ozone in ameliorating quality of life in patient affected by herpes infections thus reducing post herpetic neuralgia.

Background. Zoster-associated pain is experienced by approximately $90 \%$ of patients. Post-herpetic neuralgia (PHN) is a common consequence of an HSV infection. It is a chronic neuropathic pain condition that persists 3 months or more following an outbreak of shingles. Current interventions for PHN, such as lidocaine patches, opioids, antidepressants, anti-epileptics, electric stimulating catheters, are palliative and often fail to treat the underlying disease. Because multiple contributing factors seem to determine the severity of $\mathrm{PHN}$, the management of chronic pain requires an integrated approach.

Design. Twelve patients ( $8 \mathrm{men} / 4$ women) suffering for a burning pain in correlation with herpetic infection were electively treated with a Systemic Ozone Therapy on a blood volume of $120 \mathrm{ml}$ mixed with equal volume of ozone/oxygen mixture at $25 \mu / \mathrm{ml}$ twice a week, following once a week for 2nd and 3rd week. VAS and health questionnaire were measured.

Results. The majority of patients showed a VAS reduction in burning pain between 6 (T1) and $12 \mathrm{hr}$ (T2). At $48 \mathrm{hr}$ (T3) every patient showed an amelioration in quality of sleep. Results at 3 months were comparable.

Conclusions. Clarifying the mechanism of action triggered by ozone in reducing pain during viral infection is under investigation. We hypothesize that the moderate oxidative stress induced by Ozone enhances the antioxidant elements giving a final protection of damaged cells, renewing of neural system.

Being easy to perform, giving an improvement of night rest with no side effect and well accepted by patients. 